\title{
Factors Involved in the Choice of Oral Hygiene Products by Students in the Health Area
}

\author{
Fatores Envolvidos na Escolha de Produtos de Higiene Bucal por Estudantes da Área da \\ Saúde
}

\author{
Deison Alencar Lucietto*a; Sidimar Meira Sagaz ${ }^{\mathrm{b}}$; Caroline Muneron Reque ${ }^{\mathrm{c}}$; Ediane Casani ${ }^{\mathrm{d}}$; Mayla Prass Mathias \\ Gabrielly Vargas ${ }^{\mathrm{c}}$
}

\author{
${ }^{a}$ Fluminense Federal University, Collective Health Institute. RJ, Brazil. \\ ${ }^{b}$ Rio Grande do Sul Federal University, Gratuate Program in Administration. RS, Brazil. \\ 'Specialized Faculty in the Health of Rio Grande do Sul. Dentistry Course. RS, Brasil. \\ ${ }^{\mathrm{d} C}$ Community University of Chapecó Region, Postgraduate in Orthodonty. SC, Brasil. \\ eSouthern Indigenaus Special Sanitary District. SC, Brasil. \\ *E-mail: deisonlucietto@hotmail.com \\ Recebido em: 20/01/2020 \\ Aprovado em: 24/04/2020
}

\begin{abstract}
This study aimed to describe factors related to the oral hygiene products consumption and preference by health care providers students. It was a cross-sectional study conducted through a self-administered questionnaire with 307 students of Dentistry, Biomedicine and Physical Education. It was found that $63.5 \%$ are used to looking at inserts, $49.8 \%$ preferred to shop for at the drugstore and $32.9 \%$ bought a toothbrush monthly. Regarding the factors involved in the purchase, the main ones were indicated by dental surgeon for toothbrush (43.6\%), brand for dental floss $(26.4 \%)$ and toothpaste $(37.5 \%)$. Colgate $\AA$ and Oral-B $\AA$, respectively, were the most preferred brands for toothbrush, dental floss and toothpaste. Regarding the consumption trend as a function of monthly family income, it was found that the most important factor for the dental brush purchase was the indication of the dental surgeon, whereas the brand was the main one involved in the purchase of dental floss and toothpaste. The results suggest that both the professional indication and the brand and price perception are important factors involved in the oral hygiene products consumption by the students evaluated.
\end{abstract}

Keywords: Personal Hygiene Products. Oral Hygiene. Marketing. Dentistry.

\section{Resumo}

Este estudo teve como objetivo descrever fatores relacionados ao consumo e à preferência de produtos de higiene bucal por universitários da área da saúde. Tratou-se de estudo transversal tipo survey realizado através de questionário autoaplicado com 307 estudantes de Odontologia, Biomedicina e Educação Física. Verificou-se que 63,5\% costuma olhar encartes, 49,8\% preferia realizar suas compras na farmácia e 32,9\% comprava escova mensalmente. Quanto aos fatores envolvidos na compra, os principais foram a indicação do cirurgião-dentista para escova de dentes $(43,6 \%)$ e marca para fio dental $(26,4 \%)$ e para creme dental $(37,5 \%)$. Colgate ${ }^{\circledR}$ e Oral- ${ }^{\circledR}$, respectivamente, foram as marcas mais preferidas para escova de dente, fio dental e creme dental. Em relação à tendência de consumo em função da renda familiar mensal, constatouse que o fator decisivo mais importante para a compra da escova dental foi a indicação do cirurgião-dentista, enquanto que a marca foi o principal envolvido na compra do fio dental e do creme dental. Os resultados sugerem que tanto a indicação profissional quanto a percepção da marca e preço são importantes fatores envolvidos no consumo de produtos de higiene bucal por parte dos estudantes pesquisados.

Palavras-chave: Produtos para Higiene Pessoal. Higiene bucal. Marketing. Odontologia.

\section{Introduction}

Oral hygiene products $(\mathrm{OH})$ are indicated to remove dental biofilm, one of the main factors involved in the development of caries, gingivitis and periodontitis, the most prevalent oral diseases $^{1,2}$. Mechanical removal of dental biofilm can be performed individually by using dental brush, dental floss and dental cream $^{3}$ and also with the help of dental surgeon (DS) or guardian.

There is a wide variety of companies/industries in the market today that market brands of products for the cleaning of dental surfaces and mouth ${ }^{4}$.

Studies have shown that several factors interfere with the consumer's decision to perform the purchase of a product, such as the environment, peer influence, vendors and cultural, social and psychological characteristics ${ }^{5,6}$. In this process, companies use strategies such as brand creation and market positioning to generate thoughts, feelings and actions that stimulate the sale of their products ${ }^{7,8}$.

While the brand reveals attributes, benefits, values, status and distinction ${ }^{9-11}$, market positioning aims to improve consumers' perception of a product ${ }^{12,13}$, positively influencing the position that the brand occupies in the consumers' mind ${ }^{9,14}$ . Thus, branding and positioning are elements of great relevance to the search for preferences and advantages in the face of competition ${ }^{12,15}$.

In view of the wide range of $\mathrm{OH}$ products available today and the marketing promotion strategies adopted by the 
industries, defining criteria for the purchase of toothbrushes, toothpaste and toothpaste has not been a simple task, even for consumers with high socioeconomic and educational levels.

Due to explained above, this study aimed at describing factors related to the oral hygiene products consumption and preference by health care providers students. It is justified by the lack of research with this cut-off and also because it understands that students' behaviors patterns are largely reproduced in their professional life. Thus, it is estimated that the opinions and choices of the university students have an impact on the indications, prescriptions or suggestions of $\mathrm{OH}$ products, influencing the decision and effectuation of the purchase of other individuals.

\section{Material and Methods}

This was a cross-sectional study of the type survey 16 conducted with university students from the courses of physical Education, Biomedicine and Dentistry of a higher Education institution (HEI) in the State of Rio Grande do Sul.

All 419 students enrolled in the three undergraduate health courses offered by the HEI were invited to participate in the study. To this end, students duly enrolled, regardless of gender, age, course and period, were included. Invitations were made in the classroom, and individuals not located after two attempts were excluded. The final sample was 307 students, with a response rate of $73,3 \%$.

Prior to data collection, the study was presented and each student received a Free and informed consent (TCLE). After that, a self-complete questionnaire containing 20 questions of multiple choice was applied. These questions, specifically elaborated for the research, included sociodemographic variables, consumption habits, criteria and reasons for the consumption of $\mathrm{OH}$ products and preference for tooth brush, dental floss and dental cream brands.

The questionnaire was previously tested in 10 students who did not meet the inclusion criteria, and minor adjustments were made to increase the objectivity and clarity of the issues. The information collected was transferred to a database in the Microsoft Excel Program (2016). Later, simple descriptive statistics were performed, in terms of absolute frequency and percentage for the variables researched, using the Statistical Package for the Social Sciences (SPSS) version 23.0.

The study followed the ethical precepts of Resolution CNS No. 466/2012 and was approved by a Research Ethics Committee (CEP), via the Brazilian Platform system, through the opinion CEP number 1.502.481.

\section{Results and Discussion}

Three hundred and seven university students participated in the research, with greater participation of students of
Dentistry (250, 81.4\%), followed by Biomedicine (42, 13,7\%) and Physical Education (15, 4.9\%). There was a predominance of female $(223,72.6 \%)$, white $(268,87.3 \%)$, single $(276$, $89.9 \%)$ and 17 to 20 years old $(141,45.9 \%)$. The mean age was 22.2 years.

Regarding the financial situation, 7.5\% ( $\mathrm{n}=23)$ had monthly family income up to 1.5 minimum wages (MW); $18.9 \%(n=58)$ between 1.5 and 3.0 MW; 18.9\% $(n=58)$ between 3.0 and $4.5 \mathrm{MW} ; 21.8 \%(\mathrm{n}=67)$ between 4.5 and 6.0 MW; 16.6\% $(\mathrm{n}=51)$ between 6.0 and $10.0 \mathrm{MW} ; 12.7 \%$ $(\mathrm{n}=39)$ between 10 and $30 \mathrm{MW}$; and, finally, 3.6\% $(\mathrm{n}=11)$ with monthly family income above $30 \mathrm{MW}$.

Regarding the factors related to the $\mathrm{OH}$ products consumption, $13.7 \%$ always looked at inserts before the purchase. The most frequent places for the purchase of these products were the drugstore $(49.8 \%)$ and the supermarket (48.5\%), together adding $98.3 \%$. As for the frequency of purchase of dental brush, the largest portion reported buying it each month (32.9\%) (Chart 1).

Table 1 - Habit to look at inserts, place of purchase of products and frequency of purchase of dental brush among health university students

\begin{tabular}{|l|c|c|}
\hline \multicolumn{1}{|c|}{ Variable } & n & \% \\
\hline Habit to look at OH products inserts & & \\
\hline Never & 112 & 36.5 \\
\hline Sometimes & 153 & 49.8 \\
\hline Always & 42 & 13.7 \\
\hline where they usually buy OH products & & \\
\hline Drugstore & 153 & 49.8 \\
\hline Supermarket & 149 & 48.5 \\
\hline Does not buy & 4 & 1.3 \\
\hline Dental stores (dental) & 1 & 0.3 \\
\hline Toothbrush buying frequency & & \\
\hline Every 15 days & 12 & 3.9 \\
\hline Every month & 101 & 32.9 \\
\hline Every 2 months & 87 & 28.3 \\
\hline Every 3 months & 82 & 26.7 \\
\hline Every 6 months & 20 & 6.5 \\
\hline Every 12 months & 3 & 1.0 \\
\hline Others & 2 & 0.6 \\
\hline Total & 307 & 100.0 \\
\hline
\end{tabular}

Source: Search data.

The three main decisive factors for the effective purchase of $\mathrm{OH}$ products were: a) for toothbrush, indication of DS (43.6\%), brand (19.9\%) and price (12.1\%); b) for dental floss, brand (26.4\%), price (25.4\%) and indication of DS (22.8\%); and c) for toothpaste, brand (37.5\%), DS indication (31.6\%) and price (13.4\%) (Chart 2). 
Table 2 - Decisive factor for the realization of the purchase of $\mathrm{OH}$ products by health university students

\begin{tabular}{|l|c|c|c|c|c|c|}
\hline & \multicolumn{2}{|c|}{$\begin{array}{c}\text { Tooth } \\
\text { brush }\end{array}$} & \multicolumn{2}{c|}{ Dental floss } & \multicolumn{2}{c|}{ Toothpaste } \\
\hline Variable & $\mathbf{n}$ & $\mathbf{\%}$ & $\mathbf{n}$ & $\mathbf{\%}$ & $\mathbf{n}$ & $\mathbf{\%}$ \\
\hline Brand & 61 & $\mathbf{1 9 . 9}$ & $81^{*}$ & $\mathbf{2 6 . 4}$ & $115^{*}$ & $\mathbf{3 7 . 5}$ \\
\hline Advertisement & 8 & $\mathbf{2 . 6}$ & 11 & $\mathbf{3 . 6}$ & 15 & $\mathbf{4 . 9}$ \\
\hline Price & 37 & $\mathbf{1 2 . 1}$ & 78 & $\mathbf{2 5 . 4}$ & 41 & $\mathbf{1 3 . 4}$ \\
\hline Promotion & 5 & $\mathbf{1 . 6}$ & 4 & $\mathbf{1 . 3}$ & 3 & $\mathbf{1 . 0}$ \\
\hline $\begin{array}{l}\text { Product } \\
\text { appearance/Design }\end{array}$ & 34 & $\mathbf{1 1 . 1}$ & 18 & $\mathbf{5 . 9}$ & 6 & $\mathbf{2 . 0}$ \\
\hline $\begin{array}{c}\text { Shelf layout } \\
\text { Payment }\end{array}$ & 2 & $\mathbf{0 . 7}$ & 11 & $\mathbf{3 . 6}$ & 0 & $\mathbf{0 . 0}$ \\
\hline $\begin{array}{c}\text { condition } \\
\text { DS indication }\end{array}$ & 2 & $\mathbf{0 . 7}$ & 1 & $\mathbf{0 . 3}$ & 4 & $\mathbf{1 . 3}$ \\
\hline $\begin{array}{l}\text { Indication of } \\
\text { another person }\end{array}$ & 4 & $\mathbf{4 3 . 6 *}$ & 70 & $\mathbf{2 2 . 8}$ & 97 & $\mathbf{3 1 . 6}$ \\
\hline $\begin{array}{c}\text { Another } \\
\text { Total }\end{array}$ & 20 & $\mathbf{6 . 5}$ & 30 & $\mathbf{9 . 8}$ & 22 & $\mathbf{7 . 2}$ \\
\hline
\end{tabular}
Legend:* It refers to the most prevalent factors in each $\mathrm{OH}$ product. Source: Search data.

Regarding the positioning of the toothbrush brands, Colgate ${ }^{\circledR}(52.8 \%)$, Oral-B ${ }^{\circledR}(22.1 \%)$ and Curaprox ${ }^{\circledR}{ }^{\circledR}$ $(14,7 \%)$ were the most remembered ones (together, $89.6 \%$ ). Other brands were cited more punctual (often between $0.3 \%$ and $1.6 \%$ ).

In relation to dental floss, the three main brands were Colgate ${ }^{\circledR}(50.2 \%)$, Oral-B (27.7\%) and Sanifill ${ }^{\circledR}(10.4 \%)$. Similarly, others were reported on a smaller scale (ranging from $0.3 \%$ to $2.3 \%$ ).

Finally, regarding the first choice for toothpaste, Colgate ${ }^{\circledR}(73.9 \%)$, Oral-B ${ }^{\circledR}(12.7 \%)$, Close up ${ }^{\circledR}(4.6 \%)$ and Sorriso ${ }^{\circledR}(4.6 \%)$ led, respectively, the preference. Others were mentioned with a small frequency (between $0.3 \%$ and $2.9 \%$ ) (Table 3).

Table 3 - first choice brands in the purchase of $\mathrm{OH}$ products from health university students

\begin{tabular}{|l|c|c|}
\hline \multicolumn{1}{|c|}{ Variable } & $\mathrm{n}$ & \% \\
\hline Tooth brush & & \\
\hline Colgate $^{\circledR}$ & 162 & $\mathbf{5 2 . 8}$ \\
\hline Oral-B $^{\circledR}$ & 68 & $\mathbf{2 2 . 1}$ \\
\hline Curaprox $^{\circledR}$ & 45 & $\mathbf{1 4 . 7}$ \\
\hline Bitufo $^{\circledR}$ & 5 & $\mathbf{1 . 6}$ \\
\hline Condor $^{\circledR}$ & 3 & $\mathbf{1 . 0}$ \\
\hline Dental Clear $^{\circledR}$ & 3 & $\mathbf{1 . 0}$ \\
\hline Saniffill $^{\circledR}$ & 3 & $\mathbf{1 . 0}$ \\
\hline Sensodyne $^{\circledR}$ & 3 & $\mathbf{1 . 0}$ \\
\hline Sorriso $^{\circledR}$ & 3 & $\mathbf{1 . 0}$ \\
\hline Aquafresh $^{\circledR}$ & 2 & $\mathbf{0 . 7}$ \\
\hline Jadefrog $^{\circledR}$ & 2 & $\mathbf{0 . 7}$ \\
\hline
\end{tabular}

\begin{tabular}{|c|c|c|}
\hline $\operatorname{Kess}^{\circledR}$ & 2 & 0.7 \\
\hline Dentil $^{\circledR}$ & 1 & 0.3 \\
\hline Others* & 5 & 1.6 \\
\hline \multicolumn{3}{|l|}{ Dental floss } \\
\hline Colgate $^{\mathbb{R}}$ & 154 & 50.2 \\
\hline Oral-B $^{\circledR}$ & 85 & 27.7 \\
\hline Sanifill $^{\circledR}$ & 32 & 10.4 \\
\hline Condor $^{\mathbb{B}}$ & 7 & 2.3 \\
\hline $\operatorname{Reach}^{\circledR}$ & 5 & 1.6 \\
\hline Bitufo $^{(B)}$ & 4 & 1.3 \\
\hline Sensodyne $^{\circledR}$ & 1 & 0.3 \\
\hline Others* & 18 & 5.8 \\
\hline \multicolumn{3}{|l|}{ Toothpaste } \\
\hline Colgate $^{\circledR}$ & 227 & 73.9 \\
\hline Oral $B^{\circledR}$ & 39 & 12.7 \\
\hline Close up ${ }^{\circledR}$ & 14 & 4.6 \\
\hline Sorriso $^{\circledR}$ & 14 & 4.6 \\
\hline Sensodyne $^{\circledR}$ & 9 & 2.9 \\
\hline Contente $^{\mathbb{R}}$ & 1 & 0.3 \\
\hline Dentics $^{\circledR}$ & 1 & 0.3 \\
\hline FreeDent $^{\circledR}$ & 1 & 0.3 \\
\hline Tandy ${ }^{\circledR}$ & 1 & 0.3 \\
\hline Total & 307 & 100.0 \\
\hline
\end{tabular}

Legend:* It refers to brands mentioned by the students individually, which were not included in the questionnaire.

Source: Search data.

When analyzing the consumption trend considering the decisive factor for the purchase of $\mathrm{OH}$ products in relation to the monthly family income, it was verified that "indication of DS" was the most prevalent factor for the purchase of the "toothbrush". However, it presented the same importance as the "price" factor for individuals with a family income of up to $1.5 \mathrm{MS}$ (Chart 4).

For dental floss, differently, there was a balanced distribution among the factors: "brand" was the most prevalent for students with family income between 1.5 and 3.0 MW, between 4,5 and 6.0 MW and above $30 \mathrm{WM}$ monthly; "price", in turn, was more frequent for individuals with income up to $1.5 \mathrm{WM}$, between 3.0 and $4.5 \mathrm{WM}$ and above $30 \mathrm{WM}$. However, it also played a prominent role for those with income between 4.5 and 6.0 MW. Also, regarding dental floss, "DS indication" was the most important for those with income between 6.0 and 10.0 MW and between 10.0 and 30.0 MW. This factor also played a prominent role for individuals between 4.5 and 6.0 MW (Chart 4). 
Table 4 - tendency to buy $\mathrm{OH}$ products: decisive factor in relation to monthly family income

\begin{tabular}{|c|c|c|c|c|c|c|c|c|c|c|c|}
\hline \multirow[b]{2}{*}{ Family Income } & \multicolumn{10}{|c|}{ Decisive Factor for the Toothbrush Purchase } & \\
\hline & Brand & Prop. & Price & Promo. & Apar. & Prat. & Pgto & CD & Pes. & Another & \\
\hline Up to $1.5 \mathrm{WS}$ & 5 & 0 & $6^{*}$ & 1 & 2 & 1 & 0 & $6^{*}$ & 0 & 2 & 23 \\
\hline From 1.5 to $3.0 \mathrm{MW}$ & 12 & 1 & 7 & 2 & 6 & 0 & 0 & $24 *$ & 1 & 5 & 58 \\
\hline From 3.0 to $4.5 \mathrm{MW}$ & 12 & 2 & 9 & 0 & 5 & 0 & 0 & $25^{*}$ & 2 & 3 & 58 \\
\hline From 4.5 to $6.0 \mathrm{MW}$ & 13 & 3 & 6 & 0 & 10 & 0 & 0 & $29 *$ & 1 & 5 & 67 \\
\hline From 6.0 to $10.0 \mathrm{MW}$ & 9 & 1 & 6 & 1 & 7 & 1 & 1 & $25^{*}$ & 0 & 0 & 51 \\
\hline From 10.0 to $30.0 \mathrm{MW}$ & 8 & 1 & 1 & 1 & 2 & 0 & 0 & $21 *$ & 0 & 5 & 39 \\
\hline Over $30.0 \mathrm{MW}$ & 2 & 0 & 2 & 0 & 2 & 0 & 1 & $4 *$ & 0 & 0 & 11 \\
\hline \multirow[t]{2}{*}{ Total } & 61 & 8 & 37 & 5 & 34 & 2 & 2 & 134 & 4 & 20 & 307 \\
\hline & \multicolumn{10}{|c|}{ Decisive Factor for the Dental Floss Purchase ${ }^{2}$} & \\
\hline Family Income & Brand & Prop. & Price & Promo. & Apar. & Prat. & Pgto & $\mathrm{CD}$ & Pes. & Another & \\
\hline Up to $1.5 \mathrm{WS}$ & 6 & 1 & $9 *$ & 1 & 3 & 0 & 0 & 1 & 1 & 1 & 23 \\
\hline From 1.5 to $3.0 \mathrm{MW}$ & $17 *$ & 1 & 16 & 0 & 3 & 3 & 0 & 11 & 0 & 7 & 58 \\
\hline From 3.0 to $4.5 \mathrm{MW}$ & 13 & 5 & $17 *$ & 0 & 4 & 1 & 1 & 8 & 1 & 8 & 58 \\
\hline From 4.5 to $6.0 \mathrm{MW}$ & $19^{*}$ & 1 & 18 & 0 & 1 & 3 & 0 & 18 & 1 & 6 & 67 \\
\hline From 6.0 to $10.0 \mathrm{MW}$ & 13 & 1 & 10 & 1 & 4 & 2 & 0 & $16^{*}$ & 0 & 4 & 51 \\
\hline From 10.0 to $30.0 \mathrm{MW}$ & 10 & 1 & 5 & 2 & 1 & 1 & 0 & $15^{*}$ & 0 & 4 & 39 \\
\hline Over $30.0 \mathrm{MW}$ & $3 *$ & 1 & $3 *$ & 0 & 2 & 1 & 0 & 1 & 0 & 0 & 11 \\
\hline \multirow[t]{2}{*}{ Total } & 81 & 11 & 78 & 4 & 18 & 11 & 1 & 70 & 3 & 30 & 307 \\
\hline & \multicolumn{10}{|c|}{ Decisive factor for the Dental Cream Purchase } & \\
\hline Family Income & Brand & Prop. & Price & Promo. & Apar. & Prat. & Pgto & $\mathrm{CD}$ & Pes. & Another & \\
\hline Up to $1.5 \mathrm{WS}$ & 7 & 0 & $8^{*}$ & 0 & 1 & 0 & 1 & 5 & 0 & 1 & 23 \\
\hline From 1.5 to $3.0 \mathrm{MW}$ & $19 *$ & 5 & 11 & 0 & 1 & 0 & 1 & 16 & 1 & 4 & 58 \\
\hline From 3.0 to $4.5 \mathrm{MW}$ & $23 *$ & 2 & 6 & 2 & 1 & 0 & 1 & 18 & 1 & 4 & 58 \\
\hline From 4.5 to $6.0 \mathrm{MW}$ & $22 *$ & 5 & 9 & 0 & 1 & 0 & 0 & 22 & 2 & 6 & 67 \\
\hline From 6.0 to $10.0 \mathrm{MW}$ & 18 & 2 & 5 & 1 & 2 & 0 & 1 & $19 *$ & 0 & 3 & 51 \\
\hline From 10.0 to $30.0 \mathrm{MW}$ & $20^{*}$ & 1 & 2 & 0 & 0 & 0 & 0 & 12 & 0 & 4 & 39 \\
\hline Over $30.0 \mathrm{MW}$ & 6 & 0 & 0 & 0 & 0 & 0 & 0 & 5 & 0 & 0 & 11 \\
\hline Total & 115 & 15 & 41 & 3 & 6 & $\mathbf{0}$ & 4 & 97 & 4 & 22 & 307 \\
\hline
\end{tabular}

Legend:* Prop.= Advertisement; Promo.= Promotion.; Des = Design/appearance; Prat. $=$ shelf layout; Pgto. $=$ Payment condition; CD = indication of DS; PES.= indication of other persons. *Decisive factor was prevalent factors in each $\mathrm{OH}$ product.

Source: Search data.

Finally, for the purchase of toothpaste, the most prevalent decisive factor was "brand" for individuals with family income between 1.5 to $3.0 \mathrm{MW}$, between 3.0 and $4.5 \mathrm{MW}$, between 4.5 and $6.0 \mathrm{MW}$, between 10.0 to $30.0 \mathrm{MW}$ and for those with income greater than $30.0 \mathrm{MW}$. The "DS indication" factor was more important for students with income between 6.0 and 10.0 MW and equally important to the "brand" for individuals with income between 4.5 and 6.0 MW. Attention was drawn to the fact that shelf lay-out was not referred by any student for the cream dental product (Chart 4).

The main trigger of this study was the finding of doubts and difficulties for university students - even those of dental courses - in defining criteria for the purchase of $\mathrm{OH}$ products. In addition, the fact that no Brazilian research has been located with the same cut-off, both in terms of population and analyzed variables.
It is believed that the existence of doubts at the time of the purchase of $\mathrm{OH}$ products is influenced by the wide variety of brushes, toothpaste and dental creams available on the market $^{17}$, as well as those that are constantly launched by companies in the sector. Thus, the decision-making process for these products becomes sensitive, as pointed out by different studies at national and international level ${ }^{18-22}$.

In this sense, it is known that brands use different marketing strategies to influence the purchase of their products by seeking the combination of elements that promote distinction and pleasant experiences for consumers ${ }^{23}$, including those of products such as dental creams ${ }^{22}$. Thus, they also interfere with the behavior of those consumers who have specific knowledge about the technical attributes that are desirable for each $\mathrm{OH}$ product, as verified in this investigation.

This study had a higher number of Dentistry students due 
to the limited offer of courses and vacancies in the IHE where it was performed. The existence of more female participants is in line with the feminization trend in health professions, including dentistry ${ }^{24}$.

As for family income, the highest concentrations were between 3.0 and $4.5 \mathrm{SW}(21.8 \%$ ), followed by 1.5 to $3.0 \mathrm{SW}$ (18.9\%) and 3.0 to $4.5 \mathrm{SW}(18.9 \%)$, considered intermediate strata. In this sense, it is believed that monthly family income is an important factor involved in the choice of future profession, when many choose health courses as a possibility of ascending socially.

In addition, it is estimated that $\mathrm{OH}$ consumption habits are greatly influenced by economic issues, especially due to the high impact of $\mathrm{OH}$ product costs on the budget of Brazilian families $^{25}$. Nevertheless, according to data from the Brazilian Association of the Personal Hygiene, perfumery and Cosmetics Industries (ABIHPEC), there was an increase in consumption of oral care products in the public classes $\mathrm{C}$, $\mathrm{D}$ and $\mathrm{E}$ in the country, assigned to their higher purchasing power $^{26}$.

It called attention the fact that $63.5 \%$ of university students look at inserts, either routinely or occasionally, before the purchase of $\mathrm{OH}$ products, since they were not found in other studies on the subject. As for the places of purchase, the results point to a fairly balanced situation between drugstore (49.8\%) and supermarket (48.5\%), which can be explained by the large offer of these establishments in general.

Although there is the widely widespread recommendation that dental brush exchange should be made every three months or when bristles lose their original shape ${ }^{27}$, it was contacted in this research that most university students reported buying tooth brush monthly $(32,9 \%)$, every two months $(28,3 \%)$ or three months $(26,7 \%)$. These findings differ from a study conducted with consumers in general ${ }^{17}$ and can be explained, in large part, according to the participants' profile, with predominance of Dentistry students.

Regarding the main decisive factors for the effective purchase of products, it was verified that "DS indication", "brand" and "price" were among the three main factors for toothbrush, dental floss and toothpaste, however, with different ordinances. It is noteworthy, however, that the "price" factor was the third most important factor for the three products researched. This result is in line with the findings of investigation conducted in Nigeria ${ }^{21}$, which evidenced that brand and DS were among the main factors reported by patients for the choice of $\mathrm{OH}$ products and also, with a study conducted in Pakistan ${ }^{5}$, which identified which brand price and exposure are relevant factors to influence the purchase of these products.

Specifically, for the "toothbrush", it was observed in this research that DS indication was very important for the participants $(43,6 \%)$. This result is quite distinct from that found in the study by Bottan et al. ${ }^{17}$ which identified a small influence of this professional and that conducted by Opeodu and Gbadebo ${ }^{21}$ according to which the texture of the bristles, previous experiences and brand were the most important influencers in the choice of $\mathrm{OH}$ products. It is believed that this can be explained both by the fact that there is a higher proportion of Dentistry students and by the value attributed to the professional in the technical orientation and choice of this product. Moreover, it is estimated that advertisements of recognized brands in the country, reinforcing the presence of professionals (use of the argument of authority) may have influenced in some way the answers.

These findings are in line with the conception that the definition of consumer preferences and their purchasing decisions are associated to their cultural, social and psychological characteristics ${ }^{5}$. They are also consistent with the results of an Indian study that revealed that factors such as education, occupation and income were the main influencers for the choice of toothbrush ${ }^{28}$.

In a research published in Tunisia on the choice of medicines, it was found that large brands and those better known are preferred by the consumers, being more valued than attributes such as price, for example ${ }^{29}$. Whereas, in a study on $\mathrm{OH}$ products with students of different undergraduate courses in the city of Maceió/AL, it was identified that the brand, the ease of finding (distribution) and the appearance of the products (physical characteristics) were the most cited factors ${ }^{19}$, presenting results partially in agreement with the present investigation.

Although there is a wide variety of brands of $\mathrm{OH}$ products, the opening up of the market to imported products (especially from China) and the increased participation of regional industries in Brazil, Traditional brands such as Colgate ${ }^{\circledR}$ and Oral-B ${ }^{\circledR}$ prevailed as first and second choices, respectively, for the three products investigated in the present study. Similar results were observed in a study carried out in India, where it was found that Oral-B ${ }^{\circledR}(48.4 \%)$ and Colgate ${ }^{\circledR}(30.9 \%)$ were the most preferred ones for toothbrush and Colgate ${ }^{\circledR}(47 \%)$ and Close-Up ${ }^{\circledR}(23.3 \%)$ for toothpaste ${ }^{30}$. It is worth pointing out that the brand of products was also an important factor identified in other international studies ${ }^{5,20-22}$.

A simple search on the Internet highlights the positioning adopted by these leading brands in the market: "The number 1 mark recommended by dentists" for Colgate ${ }^{\circledR}$ and "Developed by dentists" for Oral-B ${ }^{\circledR}$, highlighting a strong professional appeal. It can then be seen that the results of this study were in line with the positioning statements presented by the main brands of $\mathrm{OH}$ products in the country.

In this sense, it is known that the industries holding these brands are constantly present in specialized newspapers and magazines, have channels of relationships with DSs, send product kits to professionals and usually sponsor congresses and events of the dental class. In this way, they make important investments to increase the consumers attraction 
and strengthen relationships with oral health professionals.

At the same time, it is believed that the reinforcement of the DS image in $\mathrm{OH}$ product advertisements ultimately generates identification with the public of future professionals and the students themselves of health courses, as observed among the respondents of this study. It is thus known that the media around $\mathrm{OH}$ products is one of the major factors involved in their purchase $\mathrm{e}^{5,20}$.

Regarding the trend of consumption of $\mathrm{OH}$ products based on monthly family income, it was observed, in general, that the "indication of DS" was more important for toothbrush, while "brand" was the most common factor associated with toothpaste and dental cream (though very close to the "price" for this product). However, the factors "shelf layout", "form of payment", "promotion" and "other people indication" were the least pointed, showing the least importance of these for the participants. It is estimated that the definition of these criteria is closely related to the participants' profile.

In this respect, a study conducted in Montes Claros/MG found a strong social influence on the choice of dentifrices ${ }^{31}$ and a systematic review on the use of toothpaste revealed that the level of schooling of consumers or their parents, especially in larger social strata, is the main factor involved in the frequency of use of this product ${ }^{32}$. Considering that the price of $\mathrm{OH}$ products is one of the main influencers in their purchase ${ }^{5}$, it is then reinforced that socio-cultural issues are important to explain preferences regarding the choice and use of $\mathrm{OH}$ products, this aspect is evidenced in other publications ${ }^{21}$.

This study had as major limitations the fact that it was performed in a single HEI. Although these aspects may have influenced the responses, it is understood that the results of this investigation are relevant because they evidenced how factors are involved in the consumption and preference of $\mathrm{OH}$ products by university students. Therefore, they can be used both to discuss the influence of brands and to induce reflections on conscious purchases and professional responsibilities in the indication of these products. It is suggested, however, that in future research there is a greater diversity of participants, in order to problematize the results per hour presented.

\section{Conclusion}

The realization of this study revealed that most health students are used to looking at inserts and that the drugstore and supermarket were their preferred locations for the purchase of $\mathrm{OH}$ products. The "DS indication" was the main factor involved in the purchase of toothbrush and the "brand" prevailed for dental floss and toothpaste.

It was concluded that Colgate ${ }^{\circledR}$ and Oral $\mathrm{B}^{\circledR}$, considered as traditional brands in the country, with constant investments in propaganda and with greater relationship to the dental class, were the best positioned ones for the three products analyzed.

Regarding the consumption trend based on family income, it was verified that the most important decisive factor for the purchase of dental brush was the "DS indication". For the purchase of dental floss, "brand", "price" and "DS indication" had similar weight. Finally, when purchasing toothpaste, the most important decisive factor was "brand". Thus, family income was relevant to understand the consumption trend from the three main factors involved in the effective purchase of $\mathrm{OH}$ products.

\section{References}

1. Pedrazzi V, Souza S, Oliveira R, Cimões R, Gusmão E. Métodos mecânicos para o controle do biofilme dentário supragengival. Rev Period 2009;19(3):26-33.

2. Casais PMM, Moreira IS, Moreira LGP, Oliveira MLL, Ribeiro EDP, Rapp GE. Placa bacteriana dental como um biofilme. Rev Fac Odontol Univ Fed Bahia 2013;43(1):61-6.

3. Brasil Ministério da Saude. Mantenha seu sorriso fazendo a higiene bucal corretamente. Brasília: MS; 2009.

4. Jardim JJ, Alves LS, Maltz M. The history and global market of oral home-care products. Braz Oral Res 2009;23(1):17-22.

5. Awais F, Shahzad H, Naheed K, Khan A. Factors influencing consumers' choices of oral hygiene products: a cross-sectional study. Makara J Health Res 2019;23(3):138-42. doi: 10.7454/ msk.v23i3.1156.

6. Rich MK. The direction of marketing relationships. J Bus Ind Mrkt. 2000;15(2):170-91. doi: 10.1108/08858620010316877

7. Churchill G, Peter JP. Marketing: criando valor para os clientes. São Paulo: Saraiva; 2013.

8. Anderson EW, Mittal V. Strengthening the satisfactionprofit chain. J Ser Res 2000;3(2):107-20. doi: $10.1177 / 109467050032001$

9. Kay MJ. Healthcare marketing: what is salient? Intl J Pharm Health Mrkt 2007;1(3):247-63. doi: $10.1108 / 17506120710818256$

10. Worlu R, Kehinde OJ, Borishade TT. Effective customer experience management in health-care sector of Nigeria: a conceptual model. IJPHM 2017;10(4):449-66. doi: 10.1108/ ijphm-12-2015-0059

11. Wood L. Brands and brand equity: definition and management. Mgmt Dec 2000;38(9):662-9. doi: $10.1108 / 00251740010379100$

12. Ries A, Trout J. Posicionamento: a batalha por sua mente. São Paulo: Pearson Makron Books; 2002.

13. Basso K, Santos CPD, Kussler LS, Müller Neto HF. Preços mais baixos para novos clientes: consequências da percepção de injustiça de preço nos clientes atuais. Rev Adm 2011;46(4):407-22. doi: 10.5700/rausp1020

14. Serralvo FA, Furrier MT. Reposicionamento de marcas: estudo de casos brasileiros. RBGN 2008;10(26):1-16.

15. Santos APC, Carvalho KM, Morato RBS. Percepção de marca: uma análise do varejo supermecadista tradicional de Aracajú após aquisições de empresas internacionais. Internext 2009;4(1):130-50

16. Zamberlan L, Rasia PC, Sousa JDS, Grison AJ, Gragliardi AO, Teixeira EB, et al. Pesquisa em ciências sociais aplicadas. Ijuí: Unijuí; 2014.

17. Bottan ER, Campos L, Odebrecht CMLR, Silveira EG, Schmitt P. Critérios adotados para a escolha da escova dental: estudo com consumidores de Florianópolis, Santa Catarina. RSBO 2010;7(2):173-81. 
18. Mialhe FL, Silva RP, Hirata E, Santos LF. Disponibilidade e custo de produtos para higiene bucal comercializados em um município paranense. Rev Fac Odontol 2008;29(2):18-21.

19. Silva Filho EP. Comportamento de consumo e características do uso de produtos de higiene bucal: estudo exploratório com alunos de graduação de Maceió. Rev PMKT 2015;16(1):86102.

20. Logaranjani A, Mahendra J, Perumalsamy R, Narayan RR, Rajendran S, Namasivayam A. Influence of media in the choice of oral hygiene products used among the population of Maduravoyal, Chennai, India. J Clin Diagn Res 2015;9(10):ZC06-8. doi: 10.7860/jcdr/2015/14552.6562

21. Opeodu OI, Gbadebo SO. Factors influencing choice of oral hygiene products by dental patients in a Nigerian teaching hospital. Ann Ib Postgrad Med 2017;15(1):51-6.

22. Sardar S, Hossain E, Chanda SR, Sarker OF, Parvez S. Consumer perception towards different toothpaste Brandsof Bangladesh. JBS 11(2):47-71.

23. Limeira TMV. Comportamento do Consumidor Brasileiro. São Paulo: Saraiva; 2017.

24. Matos IB, Toassi RFC, Oliveira MC de. Profissões e ocupações de saúde e o processo de feminização: tendências e implicações. Athenea D 2013;13(2):239-44.

25. Dutra TTB, Silva ALR, Cabral AM, Moita Neto JM, Prado Junior RR. The impact of the cost of oral hygiene products on the domestic budget in the urban region of a midsize brazilian capital city. RGO 2015;63(1):13-8. doi: 10.1590/1981863720150001000022945
26. Associação Brasileira da Indústria de Higiene Pessoal, Perfumaria e Cosméticos Caderno de Tendências ABIHPEC, n.3, 2014-2015. Available from: https://abihpec.org.br/ publicacao/caderno-de-tendencias-2014-2015/

27. Barros O, Pernambuco R, Tomita N. Escovas dentais. Rev Fac Odontol Sao Jose Campos 2001;4(1):32-7.

28. Balasubramaniam A, Diwakar MKP, Brinda B. Factors influencing selection of manual toothbrush among an urban population in Chennai City, India: a cross-sectional study. JIAPHD 2017;15(4):388-91. doi: 10.4103/jiaphd. jiaphd $49 \quad 17$

29. Smaoui F, Abdellah Kilani F, Touzani M. Country-oforigin versus brand: consumers' dilemma when choosing between generic and branded drugs in emerging countries. JPBM 2016;25(2):148-59. doi: 10.1108/JPBM-04-20140553

30. Kote S, Dadu M, Sowmya AR, Aruna D, Arora A. Knowledge, attitude and behaviour for choosing oral hygiene aids among students of Management Institutes, Ghaziabad, India. West Indian Med J 2013;62(8):758-63. doi: 10.7727/ wimj.2012.325.

31. Martins CC, Oliveira MJ, Pordeus IA, Cury JA, Paiva SM. Association between socioeconomic factors and the choice of dentifrice and fluoride intake by children. Int J Environ Res Public Health 2011;8(11):4284-99. doi: 10.3390/ijerph8114284

32. Scabar LF, Manfedini MA, Armonia PL, Narvai PC, Frazão P. Frequência de uso de creme dental segundo renda e escolaridade: uma revisão sistemática. J Health Sci Inst 2014;32(3):318-25. 